\title{
Pengaruh Dimensi Locus Of Control terhadap Prestasi Kerja Remaja yang Bekerja di Multi-Level Marketing (MLM) di Bali
}

\author{
Ni Made Puspitasari dan Komang Rahayu Indrawati \\ Program Studi Psikologi, Fakultas Kedokteran, Universitas Udayana \\ puspitasarimade@gmail.com
}

\begin{abstract}
Abstrak
Perusahaan multi-level marketing dewasa ini berkembang sangat pesat. Perusahaan MLM kini tidak hanya menjaring orang dewasa sebagai anggotanya, tetapi juga menjaring remaja yang ingin mulai mengenal dunia kerja. Salah satu hal yang memengaruhi prestasi kerja di perusahaan MLM adalah locus of control. Locus of control merupakan keyaninan seseorang terhadap penyebab peristiwa-peristiwa yang terjadi di hidupnya. Locus of control berperan dalam menentukan prestasi kerja anggota MLM. Salah satu cara untuk meningkatkan prestasi kerja anggota MLM adalah dengan meningkatkan locus of control dalam diri remaja yang bekerja di perusahaan MLM. Penelitian ini bertujuan untuk mengetahui hubungan antara locus of control dengan prestasi kerja remaja yang bekerja di perusahaan MLM.

Penelitian ini merupakan penelitian kuantitatif dengan analisis regresi sederhana. Subjek dalam penelitian ini berjumlah 78 orang. Teknik pengambilan sample dalam penelitian ini menggunakan teknik cluster random sampling. Hasil dari penelitian ini menunjukan koefisien regresi internal sebesar 11,619 , powerfull other sebesar $-14,210$ dan chance sebesar -12,316. Hasil tersebut menunjukan adanya hubungan antara dimensi locus of control terhadap prestasi kerja.
\end{abstract}

Kata kunci: locus of control, prestasi kerja, remaja, bekerja, perusahaan multi-level marketing (MLM)

\begin{abstract}
Multi-level-marketing (MLM) companies now days are growing fast. Despite employing adult, the companies are now recruiting teenager eager to earn money as parts of its operation. One factor that influencing working performance of a MLM company is locus-of-control. Locus-of-control is a conviction of a person to numerous events that may influence their life. Locus-of-control take role in examining the achievement of their MLM's member. One method to improve the performance of teenagers working in MLM is by raising their locus-of-control. The aim of this research is to examine the relationship between locus of control and working performance of teenagers in MLM.

This research used quantitative method by using simple regression analysis. Subjects of this research are 78 respondents who are working in MLM businesses. The respondents are selected using cluster random sampling technique. The results of this study showed an internal regression coefficient of 11.619 , powerfull other for -14.210 and the chance of -12.316 . These results indicate a relationship between the locus of control dimension to work performance.

Keyword: locus of control, work performance, teenagers, working, multi-level marketing company
\end{abstract}




\section{LATAR BELAKANG}

Perkembangan MLM (Multi Level Marketing) di dunia saat ini mencatatkan penjualan fantastis yaitu sebesar $\$ 139,7$ milyar (sekitar Rp1.400 triliun) di tahun 2010, meningkat menjadi $\$ 153,7$ milyar (Rp1.550 triliun) selama tahun 2011 (HowMoneyIndonesia, 2013). Amerika sebagai salah satu negara pelopor MLM, mencatat penjualan besar di dunia MLM. Pada tahun 2010, perusahaan-perusahaan MLM Amerika meraup setidaknya \$28,56 milyar (sekitar Rp290 triliun) dari penjualan produk-produk mereka di seluruh dunia termasuk Indonesia. Di tahun 2011, angka penjualan ini meningkat 4,6\% menjadi $\$ 29,87$ milyar (sekitar Rp300 triliun). Besarnya angka penjualan dari MLM membuat Amerika mendorong munculnya perusahaan MLM yang tidak hanya berbasis lokal tetapi bisa menjaring member dari seluruh dunia (HowMoneyIndonesia, 2013)

Jumlah perusahaan MLM di Indonesia terus bertambah, pada tahun 2011 bertambah menjadi 120 perusahaan dan pada tahun 2012 terdapat 300 perusahaan MLM. Pada 2009 omset bisnis MLM mencapai Rp 7,6 triliun atau mengalami pertumbuhan 5-10 persen per tahun dan pada 2010 sebesar Rp 8 triliun (RepublikaOnline, 2012). Jumlah tenaga kerja yang terlibat di perusahaan-perusahaan MLM anggota APLI tahun 2012 tercatat 9,4 juta dengan omzet Rp9,2 triliun, sedangkan tahun 2013 10,2 juta dengan omzet Rp11,7 triliun (antaranews, 2014) Sehingga, perkembangan perusahaan MLM di Indonesia tidak bisa dianggap remeh.

Studi awal yang dilakukan di Oriflame Denpasar dengan menyebarkan 50 kuesioner singkat terkait demografi distributor MLM diperoleh gambaran yang menarik, dimana usia 17-22 tahun mendominasi keanggotaan di MLM tersebut dengan pendapatan 100 ribu hingga 16 juta setiap bulan. Usia 17-22 masih dikategorikan sebagai usia remaja (Santrock, 2007). Keikutsertaan remaja menjadi distributor MLM disambut baik oleh perusahaan MLM karena dinilai memiliki potensi yang baik untuk jangka waktu panjang. Salah satu perusahaan MLM bahkan membuat program khusus untuk kaderisasi distributor anak-anak dan remaja (10-16 tahun) (Shaka, 2014).

Penyebab banyaknya remaja yang memilih MLM sebagai pilihan karier dijelaskan pada penelitian Ramaniya (2014), dimana penelitian ini mengemukakan bahwa pendapatan yang stabil, waktu yang fleksibel dan semangat kewirausahaan menjadi alasan utama remaja bergabung di MLM (Ramaniya, 2014). Bekerja di usia remaja memberikan keuntungan berupa pengalaman kerja, dimana mereka dapat lebih memahami dunia bisnis, memperoleh dan mempertahankan suatu pekerjaan, cara mengelola keuangan, belajar mengatur waktu, merasa bangga dengan keberhasilan yang diraih, dan untuk mengevaluasi tujuan-tujuan yang ditetapkan (Santrock, 2007). Hurlock (1980) menyebutkan salah satu tugas perkembangan remaja adalah persiapan mandiri secara ekonomi, remaja mulai mengikuti pelatihan dan mengenal dunia kerja. Hal tersebut didukung oleh pernyataan WHO (World Health Organization) dalam mendefinisikan remaja, menurut WHO pada usia remaja terjadi peralihan dari ketergantungan sosial ekonomi menjadi kemandirian (Sarwono, 2013)

Hal penting yang harus memiliki oleh distributor MLM adalah kepercayaan yang kuat. Kepercayaan ini meliputi kepercayaan pada kemampuan diri sendiri untuk sukses, percaya pada produk atau jasa yang dijual, dan percaya pada jaringan yang telah dibagun (Carmichael, 1991). Hubungan baik antara upline dan downline akan meningkatkan komitmen downline sehingga berpengaruh positif terhadap pendapatan mereka dan membangun kepercayaan antara upline dan downline. Upline merupakan orang yang merekrut seseorang untuk bergabung dalam bisnis MLM, sedangkan downline merupakan orang yang direkrut untuk bergabung dalam bisnis MLM. Salah satu faktor yang mempengaruhi hubungan upline dan downline dalam bisnis MLM adalah locus of control. Semakin tinggi locus of control, semakin tinggi komitmen downline terhadap uplinenya, yang akan berdampak pada kinerja mereka. Perusahaan MLM harus melihat nilai kebersamaan, membangun kepercayaan, komitmen dan menempatkan locus of control sebagai kunci untuk memotivasi downline (Salciuviene, Reardon \& Auruskeviciene dalam Meikina, 2012).

Locus of control mempunyai pengaruh yang positif terhadap kinerja karyawan, dimana semakin tinggi locus of control yang dimiliki karyawan semakin tinggi kinerja yang dimiliki dan semakin baik kinerja akan berdampak baik bagi prestasi kerja (Wuryaningsih \& Kuswati, 2013). Penelitian lain yang dilakukan pada agen penjualan berbasis internet menemukan bahwa locus of control internal merupakan salah satu faktor yang mempengaruhi prestasi kerja agen tersebut (Gulati, Bristow dan Dou, 2004). Peran locus of control terhadap prestasi kerja tidak terlihat pada penelitian yang dilakukan terhadap agen asuransi (Fauzilah dan Razak, 2011). Penelitian terhadap 60 distributor MLM menyatakan bahwa terdapat hubungan yang signifikan antara locus of control internal dan prestasi kerja distributor MLM (Patti K.D \& Zulaifah, 2007).

Locus of control pada remaja dijelaskan dalam penelitian Pratama (2015) yang melihat adanya perbedaan kematangan karir antara siswa kelas XI yang memiliki locus of control internal dan locus of control eksternal di SMK Negeri 1 Magelang. Penelitian serupa disampaikan oleh Widyastuti dan Widyowati (2015) yang mengemukakan tentang adanya hubungan positif yang signifikan antara locus of control internal dengan kematangan karir pada siswa SMK Negeri 1 Bantul. Hal ini berarti semakin tinggi locus of control internal pada siswa, semakin tinggi kematangan karirnya. Sebaliknya, semakin rendah locus of control internal siswa, maka semaki rendah kematangan karirnya.

Locus of control pada remaja mengalami perubahan orientasi, dimana dulu remaja lebih berorientasi pada locus of control internal tetapi saat ini remaja disebutkan memiliki orientasi eksternal yang lebih dominan. Perubahan tersebut dikaitkan dengan adanya perkembangan teknologi dan kemudahan akses informasi sehingga mempermudah membentuk aliansi (Freidman dan Schustack, 2008).

Berdasarkan paparan di atas maka peneliti tertarik untuk mengetahui lebih lanjut tentang pengaruh dimensi locus of control terhadap prestasi kerja remaja yang bekerja di perusahaan MLM di Bali.

\section{METODE PENELITIAN}

\section{Variabel dan definisi operasional}

Variabel adalah segala sesuatu yang berbentuk apa saja yang telah ditetapkan oleh peneliti untuk dipelajari sehingga peneliti mendapatkan informasi dan bisa menarik kesimpulan dari informasi tersebut (Sugiyono, 2014). Penelitian ini 
menggunakan dua variabel menurut Sugiyono (2014) yang terdiri dari:

Variabel bebas merupakan variabel yang nilainya mempengaruhi atau menjadi sebab perubahan variabel tergantung (Sugiyono, 2014). Pada penelitian ini terdapat tiga variabel bebas yaitu internal, powerfull other dan chance

Variabel tergantung merupakan variabel yang nilainya dipengaruhi oleh variabel bebas (Sugiyono, 2014). Pada penelitian ini yang menjadi variabel tergantung adalah prestasi kerja.

Berikut adalah definisi operasional masing masing variabel:

Locus of control

Locus of control adalah keyakinan individu tentang apa yang menjadi penyebab peristiwa-peristiwa yang terjadi di dalam hidupnya. Individu dapat memiliki keyakinan bahwa yang menjadi penyebab dari peristiwa-peristiwa yang terjadi di dalam hidupnya disebabkan oleh faktor dari dalam diri (Internal), terdapat pula individu yang memiliki keyakinan bahwa peristiwa-peristiwa yang terjadi di dalam hidupnya disebabkan oleh faktor dari luar diri ( powerful other dan chance).

Prestasi Kerja

Prestasi kerja merupakan hasil kerja karyawan baik secara kualitas maupun kuantitas yang telah dicapai karyawan dalam melaksanakan tugasnya sesuai dengan lingkup tanggung jawabnya. Penilaian prestasi kerja dalam penilitian ini disusun berdasarkan aspek-aspek prestasi kerja Rivai (Mangkunegara, 2005) yang terdiri dari kemampuan teknis, kemampuan konseptual, dan kemampuan hubungan interpersonal.

\section{Subjek penelitian}

Subjek penelitian dipilih melali teknik cluster random sampling dari populasi berupa remaja yang bekerja di perusahaan MLM di Bali. Jumlah subjek dari penelitian ini sebanyak 78 orang remaja yang bekerja di perusahaan MLM di Bali. remaja yang bekerja di MLM. Usia remaja dimulai pada umur 10-13 tahun dan berakhir pada usia 18-22 tahun (Santrock, 2007). Bergabung minimal 4 bulan, karena untuk bisa menghasilkan di perusahaan MLM diperlukan waktu setidaknya 4 bulan (Carmichael, 1991).

\section{Tempat penelitian}

Penelitian ini dilaksanakan pada bulan Maret 2017 di perusahaan MLM di Kota Denpasar.

\section{Alat Ukur}

Alat ukur dalam penelitian ini adalah skala penelitian, terdiri dari skala locus of control dan skala prestasi kerja. Skala locus of control terdiri disusun berdasarkan dimensi-dimensi locus of control Leverson (1981) yaitu Internal, powerfull other dan chance. Skala locus of control terdiri dari 35 pernyataan yang meliputi Internal 15 pernyataan, powerfull other 9 pernyataan dan chance 11 pernyataan. Skala disusun dengan menggunakan skala likert dengan empat jenjang, sangat setuju (ST), setuju (S), tidak setuju (TS), sangat tidak setuju (STS). Skor 4 untuk sangat setuju (ST), skor 3 untuk setuju (S), skor 2 untuk tidak setuju (TS) dan skor 1 untuk sangat tidak setuju (STS). Skoring dilakukan dengan menghitung total nilai masing-masing dimensi sehingga terdapat tiga nilai total, nilai total internal, nilai total powerfull other dan nilai total chance.

Skala prestasi kerja disusun berdasarkan aspek-aspek prestasi kerja menurut Veitzhal Rivai (Mangkunegara, 2005) yang terdiri dari kemampuan teknis, kemampuan konseptual dan kemampuan hubungan interpersonal. Skala prestasi kerja disusun menggunakan skala likert dengan empat jenjang, sangat setuju (ST), setuju (S), tidak setuju (TS), sangat tidak setuju (STS). Pernyataan dalam skala prestasi kerja dibagi menjadi dua kelompok yaitu favorable dan unfavorable. Bobot skor untuk pernyataan favorable akan diberikan skor 4 untuk pilihan sangat setuju (SS), skor 3 untuk setuju (S), skor 2 untuk tidak setuju (TS), dan skor 1 untuk sangat tidak setuju (STS). Skor untuk pernyataan unfavorable skor 4 akan diberikan untuk item sangat tidak setuju (STS), skor 3 untuk pilihan tidak setuju (TS), skor 2 untuk pilihan setuju (S), dan skor 1 untuk pilihan sangat setuju (STS).

Sebelum diberikan kepada subjek peneliti melakukan uji coba alat ukur. Uji coba alat ukur ini dilakukan pada 20 Februari 2017 hingga 23 Februari 2017 di kantor cabang salah satu perusahaan MLM di Denpasar. Uji coba alat ukur penelitian dilakukan dengan menyebar kuisioner kepada 30 subjek yang memenuhi persyaratan dari penelitian ini. Hasil uji coba alat ukur yaitu berupa skor, kemudian dianalisis dengan menggunakan Alpha Croncbach untuk menguji reliabilitas dan Corrected-item Total Correlation untuk validitas dengan menggunakan program SPSS versi 22.

\section{Metode pengumpulan data}

Pada penelitian ini pengumpulan data dilaukan dengan menggunakan dua buah skala, yaitu skala locus of control dan skala prestasi kerja. Pengumplan data dilakukan dengan menyebarkan skala penelitian ke yang merupakan remaja yang bekerja di perusahaan MLM. Melalui metode cluster random sampling terpilih Kota Denpasar sebagai sample penelitian.

\section{Metode analisis data}

Metode analisis data yang digunakan dalam penelitian ini adalah regresi berganda dengan program komputer Statistical for Social Science (SPSS) versi 22.0. Metode analisis regresi berganda yang digunakan untuk melihat hubungan antara dimensi locus of control, yaitu internal, powerfull other dan chance dengan prestasi kerja .

\section{HASIL PENELITIAN}

Penelitian ini merupakan penelitian korelasi dengan menggunakan regresi sederhana. Analisis regresi sederhana termasuk dalam uji statistik parametrik, oleh sebab itu peneliti melakukan uji asumsi yang meliputi uji normalitas dan uji linearitas terlebih dahulu.

Uji normalitas pada penelitian ini menggunakan teknik Kolmogrov-Smirnov pada SPSS versi 22. Berikut merupakan hasil dari uji coba normalitas: (Tabel 1. Hasil Uji Normalitas. Terlampir). 
Berdasarkan tabel di atas, sebaran data pada variabel locus of control memiliki nilai signifikansi dengan probabilitas (p) 0,2 atau memiliki nilai probabilitas di atas $0,05(\mathrm{p}>0,05)$, maka dapat dikatakan bahwa sebaran pada variabel locus of control bersifat normal. Sebaran data pada variabel prestasi kerja memiliki nilai signifikansi probabilitas (p) 0,2 atau memiliki propabilitas di atas $0,05(\mathrm{p}>0,05)$, maka dapat dikatakan bahwa sebaran pada variabel prestasi kerja bersifat normal.

Uji linearitas dilakukan untuk menguji apakah variabel locus of control dan prestasi kerja memiliki hubungan yang linear atau tidak. Berikut merupakan hasil uji linearitas yang menggunakan program SPSS versi 22. (Tabel 2. Hasil Uji Liniaritas. Terlampir).

Berdasarkan tabel di atas, terlihat bahwa taraf signifikansi untuk linearitas lebih kecil dari $0,05(\mathrm{p}<0,05)$ yaitu sebesar 0,039 . Dengan demikian dapat dikatakan bahwa hubungan antara skor variabel locus of control dan prestasi kerja bersifat linear.

Selanjutnya untuk mengetahi hubungan antar variabel peneliti melakukan analisi regresi sederhana dengan bantuan SPSS versi 22.00. Berikut adalah hasil dari analisi regresi sederhana pada SPSS versi 22.00 yang terdiri dari uji $\mathrm{F}$, uji signifikansi parameter individu, dan besarnya sumbangan efektif dimensi locus of control terhadap prestasi kerja. (Tabel 3. Hasil Uji F. Terlampir).

Uji F dilakukan untuk mengetahui apakah model regresi dapat digunakan untuk memprediksi variabel tergantung. Pada tabel di atas diperoleh bahwa $F$ hitung adalah 2,777 dengan nilai signifikansi sebesar 0,047 . Nilai signifikansi menunjukan nilai sebesar 0,047 yang mana lebih kecil dari 0,05 ( $\mathrm{p}<0,05)$, maka model regresi dapat dipercaya untuk memprediksi kontribusi variabel bebas yaitu locus of control terhadap variabel tergantung yaitu prestasi kerja.

(Tabel 4. Hasil Uji Signifikansi Parameter Individu. Terlampir). Pada tabel di atas dapat kita lihat bahwa arah hubungan yang terjadi antara dimensi locus of control internal dan prestasi kerja menunjukan arah yang positif yang dibuktikan dari nilai koefisien regresi (kolom B), yaitu $(+)$ 11,619. Tanda positif $(+)$ memiliki arti semakin tinggi locus of control internal maka semakin tinggi prestasi kerja, Hal sebaliknya terjadi pada dimensi locus of control powerfull other dan chance, dimana powerfull other dan chance menunjukan hubungan yang negatif. Tanda negatif memiliki arti bahwa terjadi hubungan yang berlawanan antara powerfull other dan chance dengan prestasi kerja. Jika powerfull other dan chance tinggi maka prestasi kerja akan rendah, ketika powerfull other dan chance rendah maka prestasi kerja akan tinggi.

Nilai signifikansi sebesar $\mathrm{p}<0,05$ yang ditunjukan pada tabel $\mathrm{di}$ atas $\mathrm{t}$ internal $=1,091 ; \mathrm{p}=0,279, \mathrm{t}$ powerfull other $=-1,647$; $\mathrm{p}=0,104, \mathrm{t}$ chance $=-1,920 ; \mathrm{p}=0,059$ menunjukan bahwa variabel locus of control yang diukur dengan dimensi internal, powerfull other dan chance diduga tidak memiliki hubungan sebab-akibat dengan variabel prestasi kerja.
Pada koefisiensi regresi (kolom B) menunjukan angka 11,619 untuk internal, -14,210 untuk powerfull other dan -12,216 untuk chance. Hal tersebut dapat dikatakan bahwa setiap peningkatan 1 nilai dari internal akan meningkatkan prestasi kerja sebesar 11,619. Sebaliknya, apabila terjadi penurunan internal sebesar 1 maka akan diprediksi akan terjadi penurunan pula pada prestasi kerja sebesar 11,619. Pada powerfull other menunjukan nilai minus (-) yang berarti bahwa setiap peningkatan 1 dari nilai dari powerfull other akan terjadi penurunan pada prestasi kerja sebesar 14,210, apabila terjadi penurunan 1 nilai dari powerfull other maka akan terjadi peningkatan pada prestasi kerja sebesar 14,210. Pada chance menunjukan nilai minus (-) yang berarti bahwa setiap peningkatan 1 dari nilai dari chance akan terjadi penurunan pada prestasi kerja sebesar 12,216, apabila terjadi penurunan 1 nilai dari chance maka akan terjadi peningkatan pada prestasi kerja sebesar 12,210. Ini dapat diketahui dari fungsi persamaan model garis regresi $\mathrm{Y}=\mathrm{a}+\mathrm{b} 1 \mathrm{X} 1+\mathrm{b} 2 \mathrm{X} 2$ $+\mathrm{b} 2 \mathrm{X} 2+\mathrm{e}$, maka perhitungannya adalah sebagai berikut $\mathrm{Y}=$ $221,624+(11,619) \mathrm{Xi}+(-14,210) \mathrm{Xp}+(-12,216) \mathrm{Xc}+\mathrm{e}$

Keterangan :

$\mathrm{Y}$ : nilai subjek pada variabel tergantung yang diprediksi

a : harga konstan atau nilai $\mathrm{Y}$ (variabel tergantung) bila

$\mathrm{X}$ (variabel bebas) adalah 0

b: koefision regresi

e : faktor kesalahan

$\mathrm{X}$ : nilai subjek pada variabel bebas

$\mathrm{Xi}$ : nilai variabel internal

Xp: nilai variabel powerfull other

Xc: nilai variabel chance

Untuk melihat sumbangan variabel bebas yaitu prestasi kerja dapat dilihat pada tabel berikut. (Tabel 5. Hasil Sumbangan Efektif Variabel Locus of Control terhadap Prestasi Kerja. Terlampir).

Berdasarkan tabel di atas, pada kolom R Square menunjukan anggka sebesar 0,101 yang mempunyai arti bahwa sumbangan variabel locus of control erhadap variabel prestasi kerja adalah sebesar $10,1 \%$. Sisanya sebesar 89,9\% merupakan sumbangan dari faktor-faktor lain. Pada kolom R, dapat kita lihat bahwa sumbangan korelasi dari variabel locus of control dan prestasi kerja adalah 0,318 .

Berdasarkan hasil dari analisi regresi sederhana yang telah dilakukan menunjukan adanya signifikansi probabilitas (p) dari korelasi yang menghasilkan angka sebesar 0,047 dapat dikatakan bahwa probabilitas $(p)<0,05$, maka hal tersebut menunjukan bahwa hipotesis nol ditolak dan hipotesis alternative diterima dan hal tersebut menunjukan bahwa adanya hubungan antara locus of control dan prestasi kerja.

Peneliti dalam penelitian ini juga akan melakukan kategorisasi skor, dimana skala dimensi locus of control dan prestasi kerja akan dikategorisasikan ke dalam lima kategori. Tujuan dari dilakukannya kategorisasi skor skala adalah untuk menempatkan subjek ke dalam kelompok yang terpisah secara berjenjang menurut kontinum berdasarkan atribut yang diukur (Azwar, 2012). Mengelompokan akan dilakukan dengan 
menggunakan rumus di bawah ini: (Tabel 6. Rumus Kategorisasi Skala. Terlampir).

Skala locus of control terdiri dari 35 pernyataan yang setiap pernyataannya memiliki skor terendah 1 dan skor tertinggi 4 . Pernyatan skala locus of control terdiri dari tiga dimensi yaitu internal 15 pernyataan dengan skor terendah 15 dan skor tertinggi 60; powerfull other dengan 9 pernyataan dengan skor terendah 9 dan skor tertinggi 36; chance terdiri dari 11 pernyataan dengan skor terendah 11 dan skor tertinggi 44 . Hasil perhitungan untuk masing-masing skala dimensi locus of control dapat dilihat pada tabel berikut. (Tabel 7. Deskripsi Statistik Data Penelitian Skala Internal. Terlampir).

Kategorisasi skala internal dapat dilihat pada tabel berikut. (Tabel 8. Kategorisasi Subjek pada Skala Internal. Terlampir).

Kategorisasi skor pada skala locus of control internal menunjukan bahwa 55, 128\% atau sebanyak 43 orang subjek termasuk pada kategori sedang. Sebanyak 43,589\% atau sebanyak 34 orang subjek berada pada kategori tinggi dan sebanyak 1 orang subjek $(1,28 \%)$ berada pada kategori sangat tinggi. Berdasarkan tabel di atas tidak ada subjek yang berada pada kategori sangat rendah dan rendah. (tabel 9. Deskripsi Statistik Data Penelitian Skala Powerfull Other. Terlampir).

Kategorisasi skala powerfull other dapat dilihat pada tabel berikut. (Tabel 10. Kategorisasi Subjek pada Skala Powerfull Other).

Kategorisasi skor pada skala powerfull other menunjukan bahwa $91,02 \%$ atau sebanyak 71 orang subjek termasuk pada kategori sedang. Sebanyak $6,41 \%$ atau sebanyak 5 orang subjek berada pada kategori rendah masing-masing sebanyak 1 orang subjek $(1,28 \%)$ berada pada kategori tinggi dan sangat rendah. Berdasarkan data di atas tidak ada subjek yang berada pada kategori sangat tinggi. (Tabel 11. Deskripsi Statistik Data Penelitian Skala Chance. Terlampir).

Kategorisasi skala chance dapat dilihat pada tabel berikut. (Tabel 12. Kategorisasi Subjek pada Skala Chance. Terlampir).

Kategorisasi skor pada skala chance menunjukan bahwa $70,51 \%$ atau sebanyak 55 orang subjek termasuk pada kategori sedang. Sebanyak $15,38 \%$ atau sebanyak 12 orang subjek berada pada kategori rendah dan sebanyak 10 orang atau sebanyak $12,82 \%$ subjek berada pada kategori tinggi. Berdasarkan tabel di atas tidak ada subjek yang berada pada kategori sangat tinggi.

Skala prestasi kerja terdiri dari 57 pernyataan yang setiap pernyataannya memiliki skor terendah 1 dan skor tertinggi 4 , sehingga skala prestasi kerja memiliki skor terendah 57 dan skor tertinggi 228. Berdasarkan perhitungan rentang skor skala prestasi kerja memiliki rentangan skor sebesar 171, yang diperoleh dari skor tertinggi (228) dikurang skor terendah (57). Standar deviasi ( $\sigma$ ) skala prestasi kerja sebesar 28,5 yang diperoleh dari rentangan skor prestasi kerja (171) dibagi
6 satuan standar deviasi. Mean teoritis $(\mu)$ skala prestasi kerja sebesar 142,5 yang diperoleh dari skor tertinggi (228) ditambah skor terendah (57) dibagi 2. Hasil perhitungan untuk skala prestasi kerja dapat dilihat pada tabel berikut. (Tabel 13. Deskripsi Statistik Data Penelitian Skala Prestasi Kerja. Terlampir).

Kategorisasi skala prestasi kerja dapat dilihat pada tabel berikut berdasarkan rumus dan table di atas adalah sebagai berikut. (Tabel 14. Kategorisasi Subjek pada Skala Prestasi Kerja. Terlampir).

Kategorisasi skor pada skala prestasi kerja menunjukan bahwa $55,13 \%$ atau sebanyak 43 orang subjek termasuk pada kategori sangat tinggi. Sebanyak $41,02 \%$ atau sebanyak 32 orang subjek berada pada kategori tinggi dan sebanyak 3 orang subjek $(3,84 \%)$ berada pada kategori sedang. Berdasarkan kategorisasi di atas tidak ada subjek yang berada pada kategori sangat rendah dan rendah.

\section{PEMBAHASAN DAN KESIMPULAN}

Berdasarkan hasil penelitian dan hasil analisis dengan menggunakan analisis regresi sederhana, maka hipotesis penelitian yang berbunyi ada hubungan antara locus of control terhadap prestasi kerja pada remaja yang bekerja di Multi Level Marketing (MLM) dapat diterima. Hal ini dibuktikan dari angka koefisien regresi dimensi locus of control terhadap prestasi kerja yaitu internal sebesar 11,610, powerfull other 14,210 dan chance sebesar -12,210.

Melalui hasil analisis juga menunjukan bahwa model regresi dapat dipercaya memprediksi variabel prestasi kerja, dimana hubungan antara locus of control dan variabel prestasi kerja adalah postif. Berdasarkan hal tersebut peneliti dapat menyipulkan ketika terjadi peningkatan pada variabel locus of control, maka akan terjadi peningkatan juga pada variabel prestasi kerja. Sebaliknya bila variabel locus of control mengalami penurunan, maka akan terjadi penurunan pada variabel prestasi kerja.

Terpenuhinya minimal subjek sebanyak 60 orang (Azwar,2010) menunjukan bahwa remaja saat ini sudah mulai memikirkan karier yang hendak dijalani, mereka mulai mencoba-coba kesempatan sehingga ketika mereka sudah dewasa, mereka siap untuk memasuki dunia kerja. Hal tersebut sesuai dengan salah satu tugas perkembangan remaja yaitu mempersiapkan karier ekonomi (Hurlock, 1980). Remaja yang telah mempersiapkan karier ekonomi sejak dini akan lebih siap menghadapi tahap perkembangan selanjutnya.

Berdasarkan usia subjek, subjek yang memiliki usia 22 tahun menempati subjek dengan jumlah yang terbanyak yaitu sebesar $42,3 \%$,diikuti oleh usia 21 tahun sebesar $20,51 \%$, usia 20 tahun sebesar $12,82 \%$, usia 19 sebesar 10,25 , usia 18 sebesar 6,41\%, dan usia 17 sebaesar 7,7\%. Usia 17 sampai usia 22 tahun pada tahap perkekembangan karier Ginzberg (Santrock, 2007) mengemukakan bahwa pada tahap ini remaja mulai mengeksplorasi, memberikan penilaian terhadap pengalaman-pengalaman kerjanya dan dikaitkan dengan 
syarat-syarat untuk bisa memasuki lapangan pekerjaan atau digunakan untuk melanjutkan pendidikan ke perguruan tinggi. Setelah melakukan eksplorasi remaja akan melakukan kristalisasi, dimana remaja sudah mampu menentukan karier yang ingin dia jalani. Remaja mempertimbangkan berbagai faktor yang ada baik faktor-faktor dari dalam diri ataupun dari luar, kemudian remaja akan memilih pekerjaan yang spesifik yang dirasa sesuai dengan potensi diri dan kesempatan yang ada.

Hasil perbandingan mean empiris dan mean teoritis pada skala locus of control hanya powerfull other yang memiliki mean empiris lebih besar dari mean teoritis. Hal tersebut menunjukan bahwa rata-rata subjek pada penelitian ini mempunyai powerfull other yang tinggi. Powerfull other merupakan keyakinan seseorang bahwa segala peristiwa yang terjadi di hidupnya merupakan pengaruh orang lain. Terkait dengan nilai rata-rata powerfull other yang tinggi pada penelitian ini dapat dihubungkan dengan pekerjaan sebagai distributor MLM, dimana distributor MLM mempunyai tugas untuk menjual barang dan merekrut member baru guna memperbesar jaringan(Collnsworth,2007). Penelitian Leverson (1981) menyatakan bahwa remaja wanita lebih dipengaruhi oleh dimensi powerfull other disbanding remaja laki-laki. Nilai rata-rata powerfull other yang tinggi bisa diakitkan dengan subjek penelitian yang didominasi wanita.

Hasil dari kategorisasi skor pada skala dimensi locus of control menunjukan hasil bahwa subjek pada skala internal sebanyak 55, 128\% subjek termasuk pada kategori sedang, $43,589 \%$ subjek berada pada kategori tinggi dan sebanyak $1,28 \%$ berada pada katagori sangat tinggi. Pada skala powerfull other menunjukan sebanyak 91,02\% subjek termasuk pada kategori sedang sebanyak 6,41\% subjek berada pada kategori rendah masing-masing sebanyak 1 orang subjek (1,28\%) berada pada kategori tinggi dan sangat rendah. Pada skala chance sebanyak $70,51 \%$ subjek termasuk pada kategori sedang, 15,38\% subjek berada pada kategori rendah dan $12,82 \%$ subjek berada pada kategori tinggi.

Hasil dari kategorisasi skor tersebut menunjukan bahwa subjek dalam penelitian ini memiliki tingkat locus of control yang beragam pada setiap dimensinya. Menurut Schultz \& Schultz (2005) ada beberapa hal yang mempengaruhi locus of control pada seseorang seperti usia, jenis kelamin, perbedaan ras, sosial ekonomi dan orang tua. Usia subjek dalam penelitian ini berusia 17-22 tahun, pada masa ini subjek dikatagorikan sebagai remaja. Masa remaja merupakan masa peralihan dari masa kanak-kanak menuju dewasa, pada masa ini terjadi perubahan-perubahan yang meliputi perubahan biologis, kognitif, dan sosio-emosional (Santrock, 2007). Leverson (1981) yang mejelaskan bahwa locus of control merupakan keyakinan individu tentang penyebab peristiwaperistiwa yang terjadi di dalam hidupnya.

Perbedaan tingkat locus of control tersebut dipengaruhi oleh perubahan-perubahan biologis, kognitif dan sosio-emosional yang sedang di alami pada masa remaja. Perubahan-perubahan tersebut juga mempengaruhi keyakinan remaja tentang apa yang menjadi penyebab dari peristiwa-peristiwa yang terjadi di dalam hidupnya. Dikaitkan dalam penelitian ini perubahan biologis, kognitif dan sosio-emosional mempengaruhi keyakinan remaja tentang apa yang mempengaruhi prestasi kerjanya di perusahaan MLM.

Kategorisasi skor pada skala prestasi kerja menunjukan bahwa sebanyak 43 orang subjek $(55,13 \%)$ termasuk pada kategori sangat tinggi. Sebanyak 32 orang subjek $(41,02 \%)$ berada pada kategori tinggi dan sebanyak 3 orang subjek $(3,84 \%)$ berada pada kategori sedang. Berdasarkan hal tersebut dapat disimpulkan bahwa sebagian besar remaja yang bekerja di MLM dalam penelitian ini memiliki prestasi kerja yang sangat baik.

Melihat hasil kontribusi efektif locus of control terhadap prestasi kerja diperoleh hasil sebesar $10,1 \%$ dan $89,9 \%$ merupakan sumbangan faktor-faktor lain di luar locus of control. Menurut Mangkunegara (2005) faktor- faktor yang bisa mempengaruhi prestasi kerja seseorang meliputi kemampuan seseorang dalam mengerjakan pekerjaan yang sesuai dengan kemampuan yang dimiliki dan motivasi seseorang untuk menunjukan prestasi kerja yang hendak di raih. Selain yang dikemukakan Mangkunegara (2005) ada faktor individu dan faktor lingkungan yang mempengaruhi prestasi kerja seseorang. Faktor individu meliputi usaha (kesiapan dalam melakasanakan tugas), abilities (sifat-sifat yang dimiliki individu) dan role/task percention (kesadaran akan tugas yang harus dikerjakan). Faktor lingkungan melingkupi kondisi fisik yang dimiliki individu, peralatan yang digunakan melaksanakan tugas, batas waktu yang diberikan dalam melaksanakan tugas, dan kesulitan yang dihadapi ketika melaksanakan tugas ( Byar \& Rue dalam Sutrisno, 2009). Locus of control merupakan bagian dari faktor individu, oleh sebab itu peneliti berasumsi bahwa faktor-faktor lain yang mempengaruh prestasi kerja di luar locus of control adalah faktor-faktor yang berasal dari lingkungan.

Nilai koefisien regresi masing-masing dimensi locus of control adalah internal sebesar 11,619, powerfull other sebesar 14,210 dan chance sebesar $\quad-12,316$ kita lihat bahwa arah hubungan dimensi locus of control internal dan prestasi kerja manunjukkan arah yang positif dengan nilai koefisien regresi (+) 11,619. Hal tersebut menunjukan bahwa semakin tinggi locus of control internal maka semakin tinggi prestasi kerja. Luthan (2006) menyatakan bahwa manajer yang memiliki locus of control internal bekerja lebih baik disbanding yang memiliki locus of control eksternal ( powerfull other dan chance). Penelitian Gulati dkk (2004) menyebutkan bahwa locus of control internal mempunyai pengaruh yang positif terhadap prestasi kerja.

Melalui prosedur penelitian dan analisi data yang sesuai, maka penelitian ini telah mencapai tujuannya yaitu mampu mengetahui bahwa dimensi locus of control memiliki pengaruh dengan prestasi kerja pada remaja yang bekerja di perusahaan Multi Level Marketing (MLM). Dimensi Internal mempunyai pengaruh positif terhadap prestasi kerja, sementara powerfull other dan chance memiliki pengaruh yang negative terhadap prestasi kerja Penelitian ini berhasil 
membuktikan hipotesis yang berbunyi ada pengaruh antara dimensi locus of control dan prestasi kerja pada remaja yang bekerja di perusahaan Multi Level Marketing (MLM) di Bali.

Berdasarkan keseluruhan pembahasan di atas, dapat disimpulakan bahwa Sumbangan efektif locus of control terhadap variabel prestasi kerja adalah sebesar $10,1 \%$. Hasil dari hubungan korelasi dari ketiga dimensi locus of control Leverson, hanya internal yang mempunyai hubungan yang positif dengan prestasi kerja sementara powerfull other dan chance mempunyai hubungan yang negatif terhadap prestasi kerja.

Hasil katagorisasi skor skala diperoleh hasil bahwa sebagian besar subjek dalam penelitian ini yang merupakan remaja yang bekerja di MLM memiliki locus of control internal yang berada pada kategori sedang $(55,128 \%)$, powerfull other pada kategori sedang $(91,02)$ dan chance berada pada kategori sedang $(70,51 \%)$ dan sebagian besar subjek memiliki prestasi kerja yang sangat tinggi.

Terkait dengan pemaparan hasil penelitian ini disarankan kepada Remaja yang Bekerja di MLM (Multi Level Marketing) sebaiknya mulai memikirkan karier yang hendak di pilih berdasarkan minat dan kemampuan. Bagi remaja yang aktif di perusahaan MLM diharapkan dapat meningkatkan locus of control yang dimiliki dengan cara rajin mengikuti seminar-seminar pengembangan diri sehingga dapat mencapai prestasi kerja yang maksimal.

Kepada orang tua hendaknya memberikan bimbingan kepada anaknya yang telah memasuki usia remaja untuk mulai mengenal dan memilih karier yang hendak dipilih sesuai dengan minat dan kemampuan anak tersebut.

Kepada perusahaan MLM, penelitian ini menunjukan kontribusi locus of control sebesar 10,1\% terhadap prestasi kerja dan ada $89,9 \%$ kontribusi dari faktor-faktor lain di luar locus of control. melihat kontribusi yang cukup rendah, peneliti menyarannya perusahaan melihat faktor-faktor lain yang bisa mempengaruhi prestasi kerja, disamping locus of control.

Penelitian selanjutnya hendaknya menggunakan sampel yang lebih banyak sehingga lebih representatif. Hasil penelitian ini menunjukan ada 89,9\% faktor-faktor lain yang mempengaruhi prestasi kerja remaja yang bekerja di MLM. Diharapkan penelitian selanjutnya dapat mengemukakan.

\section{DAFTAR PUSTAKA}

Aji, B. B. (2010). Analisis Dampak Locus Of Control Pada Tekanan Kerja, Kepuasan Kerja, dan Kinerja Auditor Internal. Fakultas Ekonomi Universitas Diponogoro .

Aji, R., Hartati, S., \& Rusmawati, D. (2010). Hubungan Locus Of Control Internal Dengan Kematangan Karir Pada Siswa Kelas XII SMK N 4 Purwekerto. Fakultas Psikologi Universitas Diponegoro .

Azwar, S. (2012). Penyusunan Skala Psikologi. Yogyakarta: Pustaka Pelajar.

Azwar, S. (2010). Reliabilitas dan Validitas. Yogyakarta: Pustaka Pelajar.
Baharudin, F., Yusuf, M., \& Karyanta, N. A. (2012). Hubungan Efikasi Diri dan Jiwa Kewirausahaan dengan Pilihan Karier Wirausaha pada Mahasiswa Anggoto Multi Level Marketing Tianshi. Jurnal Wacana Psikologi Universitas Sebelas Maret Vol.4, No 7 .

Burger, J. M. (2008). Personality: Seventh Edition. Stamford: Wadsworth

Carmichael, A. (1991). Network \& Multi-Level Marketing. Jakarta: Pustaka Delapratasa.

Collinsworth, P. (2007). Network Marketing: MLM Strategies for Success and Wealth Creation. United States of America: XOR Career Guides. Didapat dari https://www.freeebooks.net/ebook/Network-Marketing-MLM-Strategiesfor-Success-and-Wealth-Creation

Dewi, N. R., \& Zulaifah, E. (2007). Hubungan Antara Kecerdasan Emosi dan Locus Of Control Internal Dengan Prestasi Kerja Distributor Multi Level Marketing (MLM). PSIKOLOGIA / Vol. : 3 No. 1, Januari 2015

DL, W., \& Kuswati, R. (2013). Analisi Pengaruh Locus Of control Terhadap Kinerja Wartawan. Peran Perbankan Syariah Terhadap Dalam Penguatan Kapasitas UMKM Menuju Kemandirian Ekonomi Nasional . ISBN: 978- 979- 636- 147- 2

Fauzilah, \& Razak, A. (2011). The Effects of Personality Factors on Sales Performance of Takaful (Islamic Insurance) Agents in Malaysia. Internasional Journal of Business and Social Science . Vol. 2 No. 5; [Special Issue -March 2011]

Feist, J., \& Feist, G. J. (2010). Teori Kepribadian.diterjemahkan oleh: Smita Prathita Sjahputri. Jakarta: Salemba Humanika.

Freidman, H. S., \& Schustack, M. W. (2008). Keperibadian : Teori Klasik dan Riset Modern Edisi Ketiga Jilid 1. Erlangga.

Gaol, C. J. (2014). A-Z Human Capital Manajemen Sumber Daya Manusia: Konsep, Teori, dan Pengembangan Dalam Konteks Organisasi Publik dan Bisnis. Jakarta: Grasindo.

Ghufron, M. N., \& Risnawati, R. (2014). Teori-teori Psikologi. Jogjakarta: Ar-Ruzz Media.

Ghufron, M., \& Risnawita, R. (2014). Teori-teori Psikologi. j.

Griffin, R. W. (2002). Manajemen: Jilid 2 Edisi Ketujuh. diterjemahkan oleh : Gina Gania. Jakarta: Erlangga.

Gulati, R., Bristow, D. N., \& Dou, W. (2004). The Impact of Personality Variables, Prior Experience, and Training on Sales Agents' Internet Utilization and Performance. Journal of Business to Business Marketing Vol.11 .

Hasibuan, M. S. (2016). Manajemen Sumber Daya Manusia. Jakarta: PT Bumi Aksara.

Hendry, R. E. (31 Januari 2013 ). Oriflame Indonesia Targetkan Nomor Satu Dunia dalam Lima Tahun. Retrieved Desember 15, 2014, from Kabar24.com: http://m.kabar24.com/bisnis/read/20130131/11/136398/Orif lame-indonesia-targetkan-nomor-satu-dunia-dalam-limatahun

Hurlock, E. B. (1980). Psikologi Perkembangan: Suatu Pendekatan Sepanjang Rentang Kehidupan Edisi Kelima. Jakarta: Penerbit Erlangga.

Lefcourt, H. M. (1982). Locus of Control : Current Trends in Theory and Research Second Edition. New Jersey: Lawrence Erlbaum Associates, Inc., Publishers.

Leverson, H. (1981). Defferentiating Among Internality, Powerful Other, and Chance. Research with The Locus of Control Construct (Vol.1) .

Lissa, L. (2014, November 5). Jumlah Konsultan MLM Oriflame di Kantor Cabang Denpasar. (N. M. Puspitasari, Interviewer)

Luthans, F. (2006). Perilaku Organisasi. Yogyakarta: ANDI.

M.Manullang, \& Manullang, M. (2001). Manajemen Sumber Daya Manusia Edisi Pertama. Yogyakarta: BPFEYOGYAKARTA. 
Mangkunegara, A. P. (2005). Manajemen Sumber Daya Manusia Perusahaan. Bandung: PT. Remaja Kosdakarya .

Menezes,A. A. 2008. Analisis Dampak Locus of control Terhadap Kinerja dan Kepuasan Kerja Auditor Internal (Penelitian Terhadap Auditor Internal di Jawa Tengah). Tesis. Program Pasca Sarjana Fakultas Ekonomi Universitas Diponogoro

P.Robbins, S., \& Judge, T. A. (2008). Perilaku Organisasi. Jakarta: Salemba Empat.

Pambudi, P. S., \& Wijayanti, D. Y. (2012). Hubungan Konsep Diri dengan Prestasi Akademik pada Mahasiswa Keperawatan. Jurnal Nursing Studies .

Patti K.D, N. R., \& Zulaifah, E. (2007). Hubungan Antara Kecerdasan Emosional dan Locus Of Control Internal Dengan Prestasi Kerja Distributor Multi Level Marketing (MLM).

Phares, E. J. (1976). Locus of Control in Personality. New Jersey: General Learning Press.

Purwanto. (2010). Metodelogi Penelitian Kuantitatif : untuk Psikologi dan Pendidikan. Yogyakarta: Pustaka Pelajar.

Robbin, S. P., \& Judge, T. A. (2008). Perilaku Organisasi. Jakarta: Salemba Empat.

Santrock, J. W. (2007). Remaja Edisi Kesebelas Jilid 2. Jakarta: Penerbit Erlangga.

Sarwono, S. W. (2013). Psikologi Remaja. Jakarta: Rajawali Pers.

Schultz, D. P., \& Schultz, S. E. (2005). Theories Of Personality: Eighth Edition. USA: Wadsworth.

Shaka. (12 Agustus 2004). Perusahaan MLM Siapkan Program Kaderisasi Khusus Anak-Anak dan Remaja. Diperoleh 18 Maret 2015, dari Pos Ronda: http://posronda.net/2014/08/12/perusahaan-mlm-siapkanprogram-kaderisasi-khusus-anak-anak-dan-remaja/

Sitanggang, D. (10 Mei 2014). Oriflame Perbanyak Member Lewat lagu. Diperoleh pada 25 Desember 2014, dari SWA: http://swa.co.id/business-strategy/Oriflame-perbanyakmember-lewat-lagu

Skorikov, V. B., \& Patton, W. (2007). Career Development in Childhood and Adolescence. Rotterdam: Sense Publishers.

Sugyono. (2014). Metode Penelitian Pendidikan: Pendekatan Kuantitatif, Kualitatif, dan R\&D. Bandung: Alfabeta.

Suryanti, R., Yusuf, M., \& Priyatama, A. N. (2011). Hubungan Antara Locus Of Control Internal dan Konsep Diri Dengan Kematangan Karir Pada Siswa Kelas XI SMK Negeri 2 Surakarta. http://eprints.uns.ac.id/id/eprint/7560 .

SWA. (6 Desember 2007). Orang-orang Top dan Produk Andalan di Bisnis Penjualan Langsung. diperoleh pada 15 Desember 2014, dari SWA: http://swa.co.id/listed-articles/orangorang-top-dan-produk-andalan-di-bisnis-penjualanlangsung

Taylor, J. M. (2012). The Case (For and) Against Multi-Level Marketing. Consumer Awareness Institute. www.mlmwatch.org/01General/taylor.pdf

Wijayanti, E. F. (2013). Pengaruh Perhatian Orang Tua Dan Locus Of Control Terhadap Prestasi Belajar Akuntansi Siswa Kelas XI AK SMA Batik Perbaik Purworejo Tahun Ajaran 2012/2013.

Wulandani, P., Darmayanti, R. Y., \& Rifa, D. (2014). Pengaruh Locus Of Control Dengan Prestasi Kerja Auditor Dengan Gaya Kepemimpinan Situasional Sebagai Variabel Moderating. - E-Journal Universitas Bung Hatta . Vol 4, No 1 (2014) 
N. M. PUSPITASARI \& K. R. INDRAWATI

\section{LAMPIRAN}

Tabel 1

Hasil Uji Normalitas

\begin{tabular}{lll}
\hline & Locus of control & Prestasi Kerja \\
\hline Asymp.Significant & 0,2 & 0,2 \\
\hline
\end{tabular}


Tabel 2

Hasil Uji Linearitas

\begin{tabular}{lllll}
\hline & & F & Signifikansi \\
\hline Locus of control $^{\text {*1 }}$ & Between Group & (Combined) & 1,168 & 0,370 \\
Prestasi kerja & & Linearity & 4,959 & 0,039 \\
& Deviation from & & 0,426 \\
& Linearity & 1,103 & \\
\hline
\end{tabular}


Tabel 3

Hasil Uji F

\begin{tabular}{lllllll}
\hline Model & & $\begin{array}{l}\text { Sum of } \\
\text { Squares }\end{array}$ & df & $\begin{array}{l}\text { Mean } \\
\text { Square }\end{array}$ & F & Sig. \\
\hline 1 & Regression & 2331,618 & 3 & 777,206 & 2,777 & 0,047 \\
& Residual & 20713,830 & 74 & 279,917 & & \\
& Total & 23045,449 & 77 & & & \\
\hline
\end{tabular}


Tabel 4

Hasil Uji Signifikansi Parameter Individu

\begin{tabular}{|c|c|c|c|c|c|c|}
\hline \multirow[b]{2}{*}{ Mod } & & \multicolumn{2}{|c|}{$\begin{array}{l}\text { Unstandardized } \\
\text { Coefficients }\end{array}$} & $\begin{array}{l}\text { Standardized } \\
\text { Coefficients }\end{array}$ & \multirow[b]{2}{*}{$\mathrm{t}$} & \multirow[b]{2}{*}{ Sig. } \\
\hline & & $B$ & Std. Error & Beta & & \\
\hline \multirow[t]{4}{*}{1} & (Constant) & 221,624 & 30,346 & & 7,303 & 0,000 \\
\hline & $\begin{array}{l}\text { Internal } \\
\text { Powerfull }\end{array}$ & 11,619 & 10,647 & 0,129 & 1,091 & 0,279 \\
\hline & Other & $-14,210$ & 8,627 & -194 & $-1,647$ & 0.104 \\
\hline & Chance & $-12,316$ & 6,416 & -228 & $-1,920$ & 0,059 \\
\hline
\end{tabular}


N. M. PUSPITASARI \& K. R. INDRAWATI

Tabel 5

Hasil Sumbangan Efektif Variabel Locus of control terhadap prestasi kerja

\begin{tabular}{lllll}
\hline Model & $\mathrm{R}$ & $\mathrm{R}$ Squares & $\begin{array}{l}\text { Adjusted } \mathrm{R} \\
\text { square }\end{array}$ & Std. Error of the estimate \\
\hline $\mathbf{1}$ & 0,318 & 0,101 & 0,065 & $\mathbf{1 6 , 7 3 0 7 1}$ \\
\hline & Predictors: (Constant), chance, internal, powerfull other &
\end{tabular}


Tabel 6

Rumus Kategorisasi Skor Skala

\begin{tabular}{lc}
\hline Rumus & Kategori \\
\hline $\mathrm{x} \leq \mu-1,5 \sigma$ & Sangat Rendah \\
$\mu-1,5 \sigma<\mathrm{x} \leq \mu-0,5 \sigma$ & Rendah \\
$\mu-0,5 \sigma<\mathrm{x} \leq \mu+0,5 \sigma$ & Sedang \\
$\mu+0,5 \sigma<\mathrm{x} \leq \mu+1,5 \sigma$ & Tinggi \\
$\mu+1,5 \sigma<\mathrm{x}$ & Sangat Tinggi \\
\hline Keterangan : & \\
$\mu \quad$ : Mean Teoritis & \\
$\sigma \quad:$ Standar Deviasi &
\end{tabular}


Tabel 7

Deskripsi Statistik Data Penelitian Skala Internal

\begin{tabular}{ll}
\hline Deskripsi Data & Internal \\
\hline $\mathrm{X}$ min & 15 \\
$\mathrm{X}$ max & 60 \\
Range & $60-15=45$ \\
Standar Deviasi $(\mu)$ & $45 / 6=7,5$ \\
Mean Teoritis $(\sigma)$ & $(60+15) / 2=37,5$ \\
\hline
\end{tabular}


Tabel 8

Kategorisasi Subjek pada Skala Internal

\begin{tabular}{lllll}
\hline Variabel & Rentang nilai & Kategori & $\begin{array}{l}\text { Jumlah subjek } \\
\text { (orang) }\end{array}$ & Presentase \\
\hline Internal & $X \leq 26,25$ & Sangat Rendah & 0 & 0 \\
& $26,25<X \leq 33,75$ & Rendah & 0 & 0 \\
& $33,75<X \leq 41,25$ & Sedang & 43 & $55,128 \%$ \\
& $41,25<X 48,75$ & Tinggi & 34 & $43,589 \%$ \\
& $48,75<X$ & Sangat Tinggi & 1 & $1,28 \%$ \\
\hline & & \multicolumn{4}{r}{ Jumlah } & 78 & $99,99 \%$ \\
\hline
\end{tabular}


Tabel 9

Deskripsi Statistik Data Penelitian Skala Powerfull Other

\begin{tabular}{ll}
\hline Deskripsi Data & Powerfull Other \\
\hline X min & 9 \\
X max & 36 \\
Range & $36-9=27$ \\
Standar Deviasi $(\mu)$ & $27 / 6=4,5$ \\
Mean Teoritis $(\sigma)$ & $(36+9) / 2=23,5$ \\
\hline
\end{tabular}


Tabel 10

Kategorisasi Subjek pada Skala Powerfull Other

\begin{tabular}{|c|c|c|c|c|}
\hline Variabel & Rentang nilai & Kategori & $\begin{array}{l}\text { Jumlah subjek } \\
\text { (orang) }\end{array}$ & Presentase \\
\hline Powerful & $X \leq 16,75$ & Sangat Rendah & 1 & $1,28 \%$ \\
\hline \multirow[t]{5}{*}{ other } & $16,75<X \leq 19,25$ & Rendah & 5 & $6,41 \%$ \\
\hline & $19,25<X \leq 25,75$ & Sedang & 71 & $91,02 \%$ \\
\hline & $25,75<X 30,25$ & Tinggi & 1 & $1,28 \%$ \\
\hline & $30,25<X$ & Sangat Tinggi & & 0 \\
\hline & & Jumlah & 78 & $99,99 \%$ \\
\hline
\end{tabular}




\section{Tabel 11}

Deskripsi Statistik Data Penelitian Skala Chance

\begin{tabular}{ll}
\hline Deskripsi Data & Locus Of Control \\
\hline $\mathrm{X}$ min & 11 \\
$\mathrm{X}$ max & 44 \\
Range & $44-11=33$ \\
Standar Deviasi $(\mu)$ & $33 / 6=5,5$ \\
Mean Teoritis $(\sigma)$ & $(44+11) / 2=27,5$
\end{tabular}


Tabel 12

Kategorisasi Subjek pada Skala Chance

\begin{tabular}{|c|c|c|c|c|}
\hline Variabel & Rentang nilai & Kategori & $\begin{array}{l}\text { Jumlah subjek } \\
\text { (orang) }\end{array}$ & Presentase \\
\hline \multirow[t]{6}{*}{ Chance } & $X \leq 19,25$ & Sangat Rendah & 1 & $1,28 \%$ \\
\hline & $19,25<X \leq 24,75$ & Rendah & 12 & $15,38 \%$ \\
\hline & $24,75<X \leq 30,25$ & Sedang & 55 & $70,51 \%$ \\
\hline & $30,25<X 35,75$ & Tinggi & 10 & $12,82 \%$ \\
\hline & $35,75<X$ & Sangat Tinggi & 0 & 0 \\
\hline & & Jumlah & 78 & $99,99 \%$ \\
\hline
\end{tabular}




\section{Tabel 13}

Deskripsi Statistik Data Penelitian Skala Prestasi Kerja

\begin{tabular}{ll}
\hline Deskripsi Data & Prestasi Kerja \\
\hline $\mathrm{X}$ min & 57 \\
$\mathrm{X}$ max & 228 \\
Range & $228-57=171$ \\
Standar Deviasi $\mu)$ & $171 / 6=28,5$ \\
Mean Teoritis $\sigma)$ & $(228+57) / 2=142,5$ \\
\hline
\end{tabular}


Tabel 14

Kategorisasi Subjek pada Skala Prestasi Kerja

\begin{tabular}{lllll}
\hline Variabel & Rentang nilai & Kategori & $\begin{array}{l}\text { Jumlah } \\
\text { subjek } \\
\text { (orang) }\end{array}$ & Presentase \\
\hline Prestasi & $X \leq 114,75$ & Sangat Rendah & 0 & 0 \\
Kerja & $114,75<X \leq 128,25$ & Rendah & 0 & 0 \\
& $128,25<X \leq 156,75$ & Sedang & 3 & $3,84 \%$ \\
& $156,75<X 185,25$ & Tinggi & 32 & $41,02 \%$ \\
& $185,25<X$ & Sangat Tinggi & 43 & $55,13 \%$ \\
\hline
\end{tabular}

